\title{
British plants as aliens in New Zealand cities: residence time moderates their impact on the beta diversity of urban floras
}

\author{
Carlo Ricotta • Gillian L. Rapson - Ullrich Asmus • Petr Pyšek • (1) \\ Ingolf Kühn $(\mathbb{D} \cdot$ Frank A. La Sorte $\mathbb{D} \cdot$ Ken Thompson
}

Received: 10 March 2017 / Accepted: 1 September 2017 / Published online: 24 October 2017

(C) Springer International Publishing AG 2017

\begin{abstract}
Anthropogenic activities have weakened biogeographical barriers to dispersal, thereby promoting the introduction, establishment and spread of alien species outside their native ranges. Several studies have identified a number of biological and ecological drivers that contribute to the establishment of plant species in the invaded range. One long-term factor that is generally accepted as a relevant determinant of invasion success is residence time, or time since first introduction into the new region. Residence time is often an important correlate of range extent in the invaded region, such that alien species with longer
\end{abstract}

Guest Editors: Mirijam Gaertner, John R. U. Wilson, Marc W. Cadotte, J. Scott MacIvor, Rafael D. Zenni and David M. Richardson/Urban Invasions.

C. Ricotta $(\bowtie)$

Department of Environmental Biology, University of

Rome 'La Sapienza', Rome, Italy

e-mail: carlo.ricotta@uniroma1.it

G. L. Rapson

Ecology Group, Institute of Agriculture and Environment, Massey University, Palmerston North, New Zealand

\section{U. Asmus}

Department of Environmental Engineering, University of Applied Science Weihenstephan-Triesdorf, Weidenbach, Germany

P. Pyšek

Institute of Botany, The Czech Academy of Sciences, Průhonice, Czech Republic residence times in the novel environment tend to be more widely distributed. Plant species that were introduced in different regions at different times provide a unique opportunity to examine the effect of residence time on invasion success. In this paper, we examined how residence time affects the beta diversity of alien plants in selected urban floras of New Zealand and of English and Irish cities. We used an intercontinental plant exchange as a model system, comparing groups of species introduced to New Zealand and to the British Isles at different times (i.e., species native to the British Isles, British archaeophytes and British neophytes) and asked if differences in their beta diversity can be related to differences in their residence times. Our results suggest that observed patterns of beta diversity among

\author{
P. Pyšek \\ Department of Ecology, Faculty of Science, Charles \\ University, Prague, Czech Republic \\ P. Pyšek \\ Department of Botany and Zoology, Centre for Invasion \\ Biology, Stellenbosch University, Matieland 7602, South \\ Africa \\ I. Kühn \\ Department of Community Ecology, Helmholtz Centre \\ for Environmental Research - UFZ, Halle, Germany \\ I. Kühn \\ German Centre for Integrative Biodiversity Research \\ (iDiv) Halle-Jena-Leipzig, Leipzig, Germany
}


the urban floras of New Zealand and of English and Irish cities can be attributed to a combination of residence time and of pre-adaptation to urban habitats that evolved, or were filtered in association with human activities, before the species were introduced into the invaded range.

Keywords Archaeophytes - Cities - Date of naturalization · Invasion · Neophytes · Pre-adaptation to urban habitats · Urban invasions

\section{Introduction}

Anthropogenic activities have promoted the establishment of increasing numbers of species outside their native ranges, resulting, in many cases, in serious ecological and economic impacts (Vilà et al. 2011; Pyšek et al. 2012; Simberloff et al. 2013; Blackburn et al. 2014; Kumschick et al. 2015). Biological invasions occur in a wide range of habitats, and are especially frequent in disturbed and human-transformed environments (Chytrý et al. 2008b; Pyšek et al. 2010), which makes cities particularly rich in alien species (Pyšek 1998; Chocholoušková and Pyšek 2003; La Sorte et al. 2007; Knapp et al. 2008; Aronson et al. 2014). Cities are often located in pre-existing biodiversity hot spots, which provide a high diversity of habitats (Kühn et al. 2004). In addition, cities may even provide novel habitats such as walls and roofs (Nedelcheva 2011; Fornal-Pieniak and Chyliński 2012) or urban brownfields (Bonthoux et al. 2014). Human disturbance in cities also provides distinctive environmental conditions which allow the naturalization of many alien species. For example, the 'urban heat island effect' may promote the establishment of species with higher temperature requirements or tolerance for arid environments whose distributions are limited by the cooler temperatures of the surrounding landscapes (Sukopp and Werner 1983). Fundamentally, though, the conditions determining

F. A. La Sorte

Cornell Laboratory of Ornithology, Cornell University, Ithaca, NY 14850, USA

K. Thompson

Department of Animal and Plant Sciences, University of Sheffield, Sheffield, UK alien species richness in urban areas are not different from those in rural areas; urban areas simply extend the environmental axis of the rural-urban gradient (i.e. taking proportions and numbers of habitats, geological substrates and climatic conditions into account) to more extreme values (Kühn et al. 2017). Given the increasing availability of long-distance anthropogenic vectors for dispersal, urban areas also represent important immigration sources for many alien species, which can then disperse into the surrounding landscapes. This renders urban floras a suitable tool for investigating the effects of biological invasions on alpha and beta diversity of species assemblages ( $\mathrm{La}$ Sorte et al. 2007, 2008; Ricotta et al. 2009, 2012).

Several biotic and abiotic drivers of biological invasions have been proposed, based on various methodological approaches including refined statistical models and theoretical frameworks (Pyšek and Richardson 2007; van Kleunen et al. 2010a, b). One long-term factor that is generally accepted as a crucial determinant of invasion success is residence time, or time since first introduction into a new region (Rejmánek 2000; Richardson and Pyšek 2006). Residence time is often an important correlate of range extent in the invaded regions, such that alien species with longer residence times in the novel environment tend to be more widely distributed (Castro et al. 2005; Pyšek and Jarošík 2005; Williamson et al. 2009; Gassó et al. 2010; Pyšek et al. 2015).

Interest in the spatial occupancy of alien plants is also prompted by the concern that their spread tends to homogenize the biotas of invaded regions, reducing the beta diversity of urban floras (McKinney 2004, 2006; Kühn and Klotz 2006; La Sorte and McKinney 2006; La Sorte et al. 2007, 2014; Lososová et al. 2012; Ricotta et al. 2012, 2014), thus making these increasingly similar to each other (McKinney and Lockwood 1999; Winter et al. 2009). The direction and strength of those impacts depend on residence time. In European cities, archaeophytes, which are typically weeds of arable fields or ruderal plants introduced into Europe from the Mediterranean basin and south-eastern European steppes between the Neolithic period $(\sim 4000 \mathrm{BC})$ and the European discovery of the New World ( $\sim 1500$ AD), tend to increase the floristic homogenization of urban floras (Ricotta et al. 2014; Lososová et al. 2016). By contrast, most neophytes (species introduced after $1500 \mathrm{AD}$, following major changes in human movement, 
commerce and industry) have not yet reached their maximum geographic and environmental ranges, and therefore show idiosyncratic distribution patterns that contribute to the current differentiation of urban floras (Williamson et al. 2009; Gassó et al. 2010; Essl et al. 2011).

Another important factor that promotes the establishment of species outside their native ranges is preadaptation to the environmental conditions of the invaded habitat (La Sorte and Pyšek 2009; Pyšek et al. 2015). To become established, alien plants need to pass through ecological filters, which select the species that are able to survive and grow under the conditions of the new habitat. In this view, archaeophytes are likely to promote floristic homogenization among urban areas not only because they have had enough time to spread over large geographic regions, but also due to their marked ecological preferences for rural and disturbed environments (Sádlo et al. 2007; Chytrý et al. 2008a, b), which enable them to persist within anthropogenic habitats.

The goal of this study is to analyse how residence time influences the impact of alien plants on the beta diversity of urban floras, and how it interacts with other factors such as pre-adaptation to the environmental conditions of the invaded habitats. To this end, we used an intercontinental plant exchange as a model system, comparing groups of species introduced to cities of New Zealand and the British Isles at different times and asking if differences in their beta diversity can be related to differences in their residence times and pre-adaptation to urban habitats.

\section{Data}

Our checklists included only spontaneously occurring naturalized species forming self-reproducing populations outside cultivation (Richardson et al. 2000). For the urban floras of New Zealand (NZ) we used 11 cities sampled by Asmus and Rapson (2014) in the lower North Island (Figs. 1, 2), but updated nomenclature and made minor reassignments for taxa not currently accepted as present in New Zealand according to the plants' database of the Landcare Research (http://nzflora.landcareresearch.co.nz). Each species in the New Zealand urban floras was designated as native or alien according to Asmus and Rapson (2014). The alien species were then assigned to one of three groups distinguished by their status in the urban floras of one Irish and 9 English cities (Table 1) developed from those studied by La Sorte et al. (2008) and Ricotta et al. (2012, 2014): (i) species native to the British Isles, termed here BI natives, (ii) occurring there as archaeophytes (BI archaeophytes) or (iii) as neophytes (BI neophytes). Nomenclature follows Stace (2010). Assignments of status of archaeophyte and neophyte follow Stace (2010) and the Online Atlas of the British and Irish Flora (http://www.brc.ac.uk/ plantatlas/).

From a total of 477 species in NZ urban areas, 418 were classified as alien to New Zealand, of which 146 were classified as BI native, 42 as BI archaeophyte, and 89 as BI neophyte (Table 1). Note that, while BI natives, BI archaeophytes and BI neophytes were classified according to their status in the urban floras of selected English and Irish cities, thus reflecting a more or less prolonged colonization of urban environments, some of the $141 \mathrm{NZ}$ alien species not found in the urban floras of the 10 English and Irish cities might still be BI natives, BI archaeophytes or BI neophytes that are present in other cities of the British Isles, but just by chance missing from the cities used in this study. Nonetheless, the diversity in location and size of the English and Irish cities used in this study (see Ricotta et al. 2012) should provide a meaningful sample of the urban flora of the British Isles, sufficient for the kinds of inferences made in this study.

The earliest records of 274 alien species (145 BI natives, $40 \mathrm{BI}$ archaeophytes and $89 \mathrm{BI}$ neophytes) were extracted from the NZ Floras (Healy and Edgar 1980; Webb et al. 1988; Edgar and Connor 2000), with additional data for grasses taken from herbarium specimens housed at the Herbarium of the Auckland War Memorial Museum (AK, Auckland), the Herbarium of the Museum of New Zealand Te Papa Tongarewa (WELT, Wellington), and the Allan Herbarium (CHR, Lincoln). The earliest date is 1832 for Plantago major, Rumex crispus, Sonchus oleraceus and Stellaria media (all BI natives), and the most recent is 2012 for the BI neophyte Anisantha madritensis.

\section{Methods}

For the $274 \mathrm{NZ}$ alien species with a known residence time, we performed pairwise comparisons of the beta diversity estimates for all groups of alien species (BI 


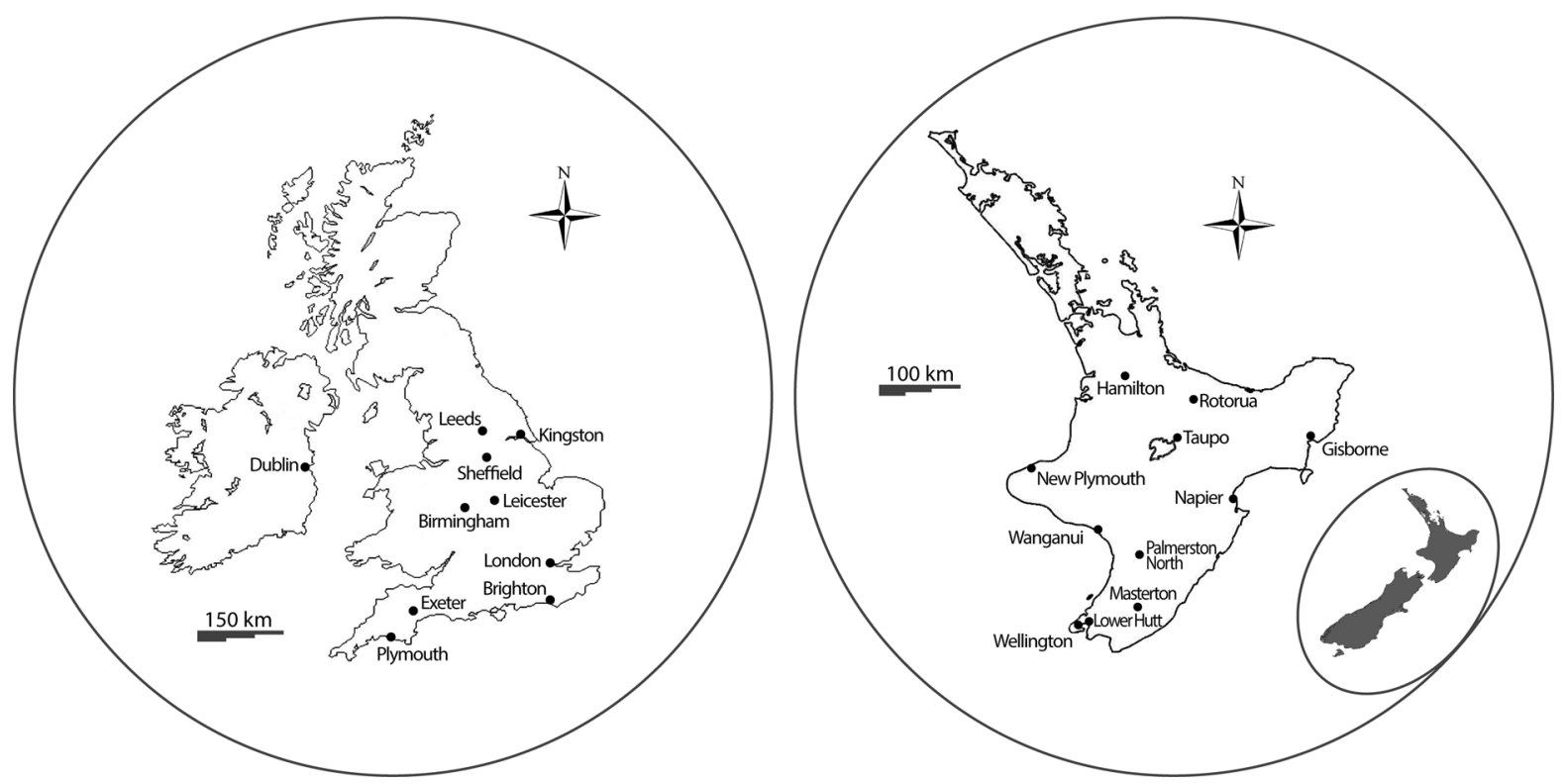

Fig. 1 Location map of cities sampled in the British Isles and in the lower North Island of New Zealand

native, BI archaeophyte and BI neophyte) among the BI and NZ urban floras. For each group of alien species, we calculated a dissimilarity matrix between pairs of cities using the Jaccard dissimilarity index, defined as $J=(b+c) /(a+b+c)$. The index considers the number of species present in both cities (a), the number of species present only in the first city (b), and the number of species present only in the second city (c). Unlike other dissimilarity measures, such as the Simpson index $S=\min \{b, c\} /(a+\min \{b, c\})$, the Jaccard dissimilarity is symmetric in handling $b$ and $\mathrm{c}$, thus providing a more balanced result with respect to the total species richness of the two sites being compared and a more complete overview of the components of pairwise beta diversity (see Lososová et al. 2016; Podani and Schmera 2016).

We next tested for differences in the mean floristic distance of individual cities from their group's centroid. Using the PermDisp program (Anderson 2004) we calculated the dissimilarity of each city from the corresponding group's centroid. Then, we used a permutation $t$ test procedure based on 9999 randomizations of least-squares' residuals to test for differences in the mean dissimilarity from the group centroid between the selected groups of cities. The same procedure was used to test for differences between the beta diversity of BI natives, BI archaeophytes, and BI neophytes in the floras of the English and Irish cities with that of the same species' groups in the New Zealand urban floras.

We also tested for differences in the time of introduction to NZ of the three groups of alien species, and in their number of occurrences in the urban floras of New Zealand and the British Isles (permutation $t$ test procedure with 9999 randomizations).

Using the same procedures, we finally tested for differences in beta diversity of the NZ urban floras for a reduced pool of alien species that were all introduced to NZ during the same period 1870-1950. However, due to the limited number of available species, we limited our comparison to two groups of alien species: BI natives and archaeophytes (75 and 17 species, respectively) vs. BI neophytes (57 species). The reasons for limiting the comparison to a reduced pool of species were twofold: (i) to minimize the influence of time of introduction on the beta diversity of the NZ urban floras (see below), and (ii) to limit the analysis to species that had sufficient time since introduction to expand their invaded ranges and colonize NZ cities.

\section{Results}

The estimates of beta diversity for BI natives, BI archaeophytes, and BI neophytes were each significantly lower among BI urban floras than among NZ 

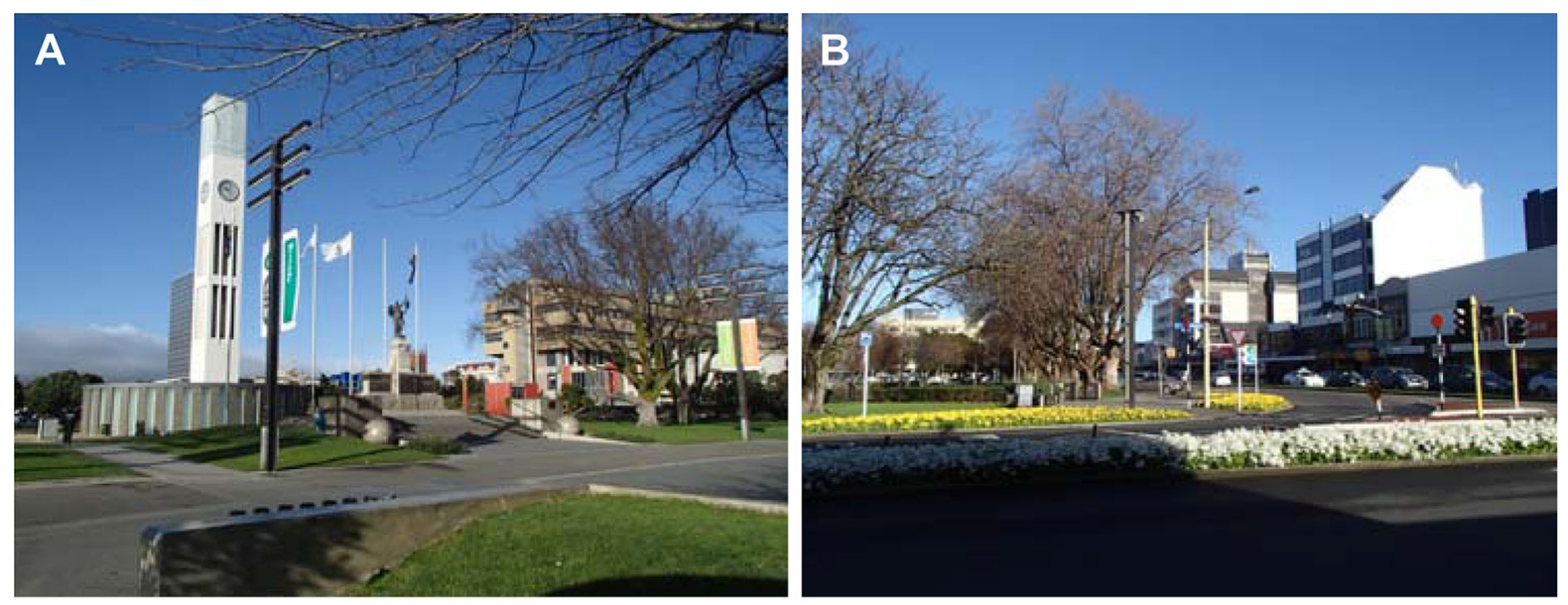

\section{C}
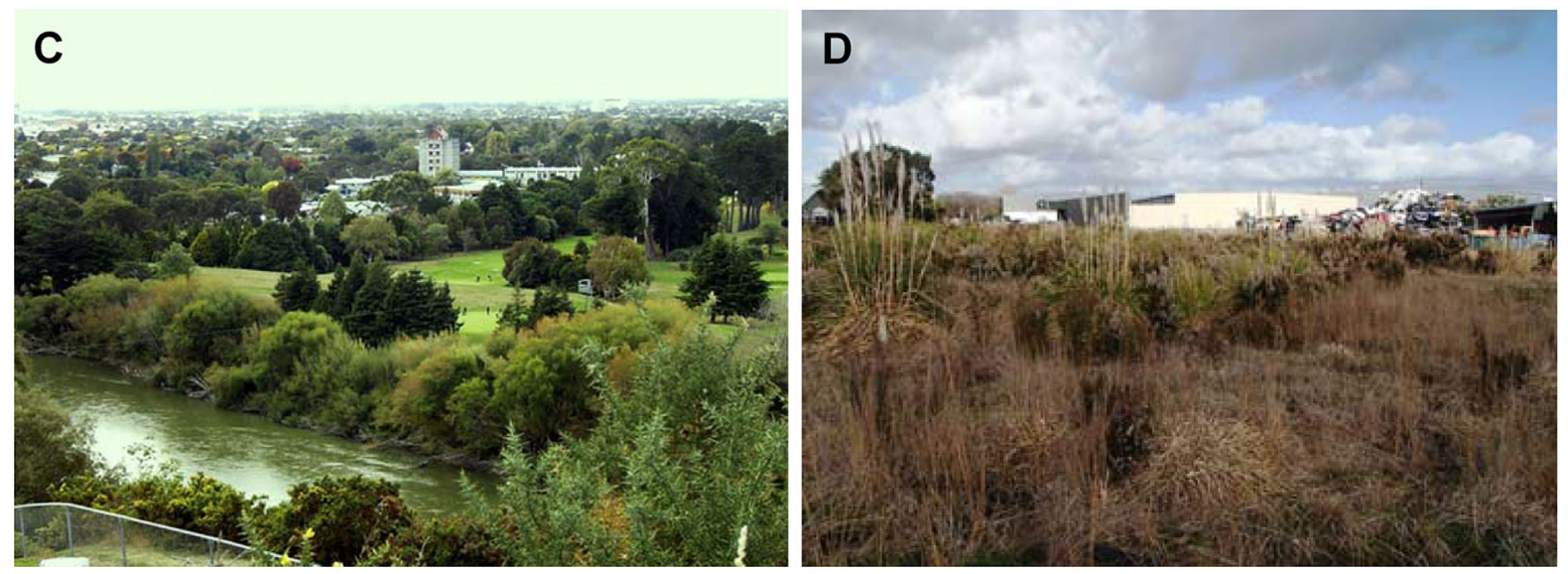

Fig. 2 Urban habitats in Palmerston North: A the urban centre; B formal plantings on the shopping hub of Broadway; C Manawatu River and golf course looking across town; D waste land on undeveloped commercial site. All images were supplied by Gillian Rapson

urban floras $(p<0.05)$. Among BI urban floras, BI natives, and BI archaeophytes, which have had more time to colonize English and Irish cities, had lower beta diversity than BI neophytes, although the difference between BI archaeophytes and BI neophytes was not significant at $p<0.05$ (Fig. 3). Likewise, among NZ urban floras, the beta diversity of BI neophytes was significantly higher than that of BI natives and BI archaeophytes, whose estimates of beta diversity did not differ significantly $(p<0.05)$. This pattern accords with the differences in residence times of the three groups of NZ aliens (Table 2). On average, BI natives (mean date of introduction \pm SD: $1891 \pm 38$ ) and archaeophytes $(1890 \pm 37)$ were introduced in New Zealand significantly earlier than BI neophytes $(1909 \pm 42)$, thus having more time to colonize larger invaded ranges.

In the English and Irish cities, BI natives and BI archaeophytes showed a significantly higher number of occurrences $(7.99 \pm 2.77$ for BI natives and $7.12 \pm 2.92$ for BI archaeophytes) compared to BI neophytes $(5.19 \pm 3.43)$. The same pattern was observed for the NZ cities ( $5.55 \pm 3.76$ for BI natives, $5.63 \pm 3.45$ for BI archaeophytes and $4.46 \pm 3.23$ for BI neophytes), although in this case, due to the short residence times in the invaded habitat, the observed differences were not statistically significant at $p<0.05$ (see Table 2). Note that for the 34 alien species found in all NZ urban floras their mean date of introduction is $1875 \pm 27$, meaning that the mean residence time required for colonizing all NZ cities used in this study is approximately 140 years.

Limiting the analysis to the alien species introduced to NZ in the period $1870-1950$, we found that the differences in residence time and number of occurrences in the NZ urban floras between BI natives and archaeophytes $(1896.31 \pm 25.20 ; 4.75 \pm 3.48)$ and 
Table 1 Summary data for each of the urban floras of New Zealand and the British Isles used in this study, including the total number of species, the number of species designated as native and alien, and the number of alien species in the NZ floras designated as species native to the British Isles (BI Nat), species identified as archaeophyte in the British Isles (BI Arc) and species identified as neophyte in the British Isles (BI Neo)

\begin{tabular}{|c|c|c|c|c|c|c|c|}
\hline \multirow[t]{2}{*}{ City } & \multicolumn{6}{|c|}{ Species richness } & \multirow[t]{2}{*}{ Source } \\
\hline & Total & Native & Alien & $\begin{array}{l}\text { BI } \\
\text { Nat }\end{array}$ & $\begin{array}{l}\text { BI } \\
\text { Arc }\end{array}$ & $\begin{array}{l}\text { BI } \\
\text { Neo }\end{array}$ & \\
\hline \multicolumn{8}{|l|}{ New Zealand } \\
\hline Gisborne & 189 & 12 & 177 & 69 & 26 & 37 & Asmus and Rapson (2014) \\
\hline Hamilton & 238 & 18 & 220 & 89 & 23 & 46 & \\
\hline Lower Hutt & 174 & 19 & 155 & 72 & 19 & 33 & \\
\hline Masterton & 170 & 12 & 158 & 73 & 25 & 32 & \\
\hline Napier & 172 & 9 & 163 & 61 & 23 & 31 & \\
\hline New Plymouth & 199 & 22 & 177 & 66 & 15 & 34 & \\
\hline Palmerston North & 194 & 9 & 185 & 80 & 27 & 37 & \\
\hline Taupo & 166 & 11 & 155 & 74 & 19 & 35 & \\
\hline Rotorua & 177 & 33 & 144 & 69 & 16 & 24 & \\
\hline Wanganui & 223 & 23 & 200 & 82 & 19 & 47 & \\
\hline Wellington & 204 & 16 & 188 & 71 & 20 & 41 & \\
\hline \multicolumn{8}{|l|}{ British Isles } \\
\hline Birmingham (UK) & 651 & 459 & 192 & 116 & 27 & 38 & Cadbury et al. (1971) \\
\hline Brighton (UK) & 592 & 384 & 208 & 115 & 29 & 45 & Hall (1980) \\
\hline Dublin (Ireland) & 348 & 223 & 125 & 90 & 22 & 32 & Jackson and Skeffington (1984) \\
\hline Exeter (UK) & 547 & 376 & 171 & 119 & 28 & 35 & Ivimey-Cook (1984) \\
\hline $\begin{array}{l}\text { Kingston upon Hull } \\
\text { (UK) }\end{array}$ & 786 & 467 & 319 & 123 & 33 & 56 & $\begin{array}{l}\text { Crackles (1990), Middleton (1998), Middleton (pers. } \\
\text { comm.) }\end{array}$ \\
\hline Leeds (UK) & 460 & 326 & 134 & 97 & 22 & 27 & Lavin and Wilmore (1994) \\
\hline Leicester (UK) & 646 & 428 & 218 & 118 & 29 & 45 & Primavesi and Evans (1988) \\
\hline London (UK) & 1251 & 674 & 577 & 133 & 40 & 74 & Burton (1983) \\
\hline Plymouth (UK) & 842 & 540 & 302 & 139 & 36 & 57 & Ivimey-Cook (1984), Stevens (1990) \\
\hline Sheffield (UK) & 799 & 497 & 302 & 116 & 33 & 53 & Shaw (1988), Hodgson (pers. comm.) \\
\hline
\end{tabular}

BI neophytes $(1899.11 \pm 26.02 ; 4.68 \pm 3.26)$ were no longer significant at $p<0.05$. Likewise, among NZ urban floras, the estimates of beta diversity between BI natives and archaeophytes and BI neophytes did not differ significantly at $p<0.05$ (Fig. 4), meaning that differences in beta diversity are mainly driven by differences in residence time.

\section{Discussion}

Our results demonstrate that turnover (i.e., beta diversity) of alien species among NZ cities strongly depends on their residence time in the invaded range
(Wilson et al. 2007; Williamson et al. 2009; Gassó et al. 2010; Pyšek et al. 2015). In NZ, all alien species in our database were introduced after the European colonization from the late 1820 s, thus confining their residence times to less than 200 years. From this perspective, the residence times of BI neophytes in NZ, which are on average 20 years shorter than those of BI natives and archaeophytes, have likely limited the opportunity for these species to expand their invaded ranges to all urban areas with suitable habitat. Accordingly, BI natives and BI archaeophytes, which have had more time to colonize NZ cities, have lower beta diversity and a higher number of occurrences in $\mathrm{NZ}$ urban floras compared to BI neophytes. 

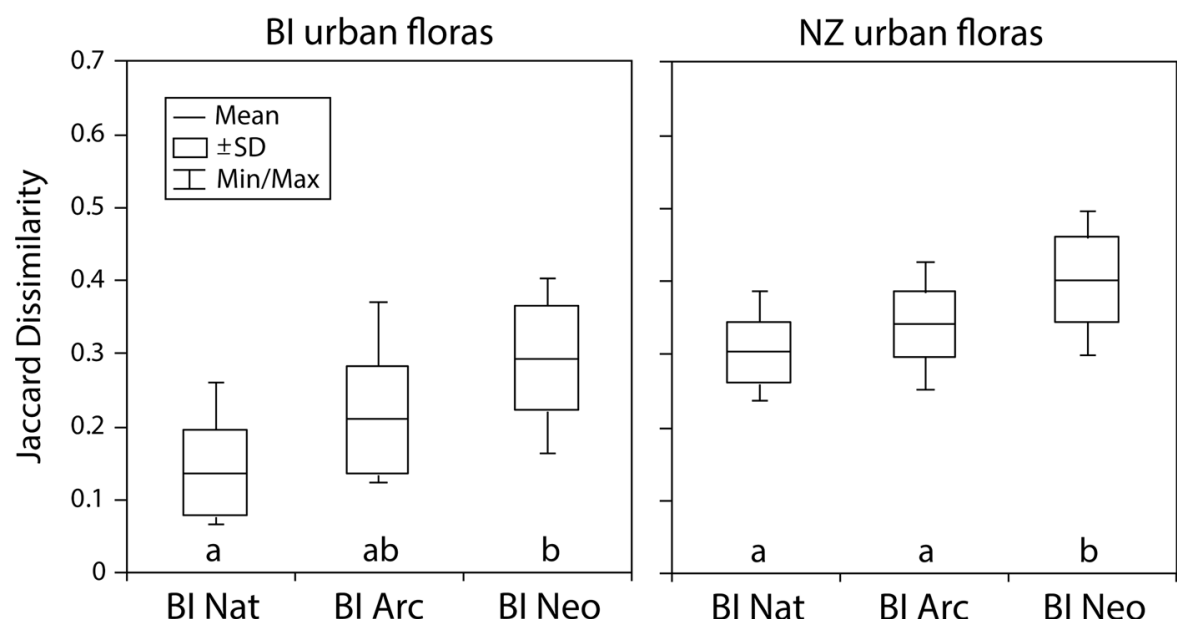

Fig. 3 Pairwise comparisons of all alien species' groups in the $\mathrm{BI}$ and $\mathrm{NZ}$ urban floras. Box plots show the distribution of Jaccard dissimilarities of individual urban floras from the corresponding group's centroid. Different letters indicate significantly different distributions at $p<0.05$ (permutation

$t$ test with Holm adjustment for multiple tests based on 9999 randomizations of least squares residuals). BI Nat $=$ species native to the British Isles; BI Arc = species identified as archaeophyte in the British Isles; BI Neo = species identified as neophyte in the British Isles

Table 2 Mean (SD) number of occurrences for all alien species' groups in the 11 urban floras of New Zealand and the 10 urban floras of the British Isles, together with the mean (SD) date of introduction for all alien species' groups in the NZ urban floras

\begin{tabular}{lcrr}
\hline & BI Nat & BI Arc & BI Neo \\
\hline Number of occurrences in the BI urban floras & $7.97(2.77)^{\mathrm{a}}$ & $7.18(2.95)^{\mathrm{a}}$ & $5.19(3.43)^{\mathrm{b}}$ \\
Number of occurrences in the NZ urban floras & $5.55(3.76)^{\mathrm{a}}$ & $5.63(3.45)^{\mathrm{a}}$ & $4.46(3.23)^{\mathrm{a}}$ \\
Date of introduction in the NZ urban floras & $1891.12(38.24)^{\mathrm{a}}$ & $1889.90(36.68)^{\mathrm{a}}$ & $1909.46(41.55)^{\mathrm{b}}$ \\
\hline
\end{tabular}

Different letters indicate significantly different distributions $(p<0.05$, permutation t-test with Holm adjustment for multiple tests based on 9999 randomizations). BI Nat = species native to the British Isles; BI Arc $=$ species identified as archaeophyte in the British Isles; BI Neo = species identified as neophyte in the British Isles

While the minimum residence time of a given naturalized species is inferred from the first known record of that species in its invaded range, further multiple naturalization events of that species, even from different source populations, can continue after that first date (e.g., Veltman et al. 1996), thus reinforcing observed differences in the invasion patterns of species with different residence times. Apart from their earlier time of introduction, the low beta diversity of BI archaeophytes among NZ cities is consistent with previous investigations showing that, due to their marked preferences for disturbed environments, this group of alien species exhibits low beta diversity among urban areas across Europe (Kühn and Klotz 2006; La Sorte et al. 2008; Ricotta et al. 2012, 2014; Lososová et al. 2016) and the northeastern United States (La Sorte et al. 2007).
Although BI natives and BI archaeophytes had longer residence times than BI neophytes, residence time is likely the most relevant aspect of a more complex invasion process driving the observed differences in beta diversity. An important source of variation can be attributed to pre-adaptations to available habitats and to species' value for cultivation (Pyšek et al. 2009, 2015). In this study, BI natives, BI archaeophytes and BI neophytes were classified according to their native/alien status in Europe but also to their presence in a range of urban floras of English and Irish cities. This classification reflects a sorting mechanism by which the selected species need to pass two urban filters in the British Isles and in New Zealand. Hence, these three groups of species were all to some extent pre-adapted to urban environments, such that, minimizing the differences in residence 


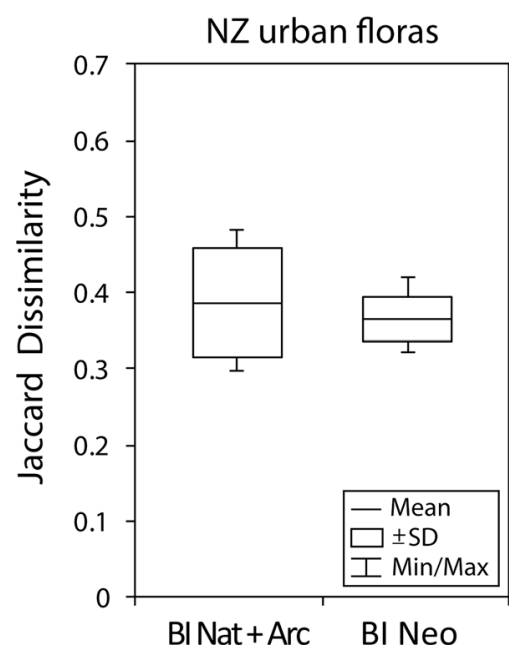

Fig. 4 Comparison of BI natives and BI archaeophytes vs. BI neophytes among the NZ urban floras using only species introduced to NZ in the period 1870-1950. Box plots show the distribution of Jaccard dissimilarities of individual urban floras from the corresponding group's centroid. The two groups are not significantly different at $p<0.05$ (permutation $t$ test based on 9999 randomizations of least squares residuals). BI $\mathrm{Nat}+\mathrm{Arc}=$ species native to the British Isles and species identified as archaeophyte in the British Isles; BI Neo = species identified as neophyte in the British Isles

time, the beta diversity in NZ cities did not differ significantly among the three groups of alien species.

However, the prolonged urban history of the BI natives and BI archaeophytes has most likely indirectly favored the colonization of the same habitats outside the species' native ranges. For instance, the typical archaeophyte in the BI is an agricultural weed, while the largest source of neophytes is intentional introductions for horticulture or gardening (Stace and Crawley 2015). Therefore, the direct association of BI archaeophytes with agriculture and human-disturbed habitats is likely to have contributed to their early introductions into New Zealand since these introductions took place during the early development of agriculture there (see La Sorte and Pyšek 2009 for a North-American analogy). In the 19th century, in the early phase of the European colonization of NZ, out of the entire pool of BI natives, BI archaeophytes and BI neophytes that became naturalized in NZ, roughly three-quarters $(73.0 \%)$ consisted of BI natives and BI archaeophytes. This ratio decreased to $57.7 \%$ during the 20th century. This is because the earliest settlers brought agricultural and crop seed (often contaminated with seeds of other species) and comparably fewer ornamental species (Thomson 1922; Druett 1983). Other alien species were likely introduced in animal fodder. Accordingly, most BI natives and BI archaeophytes were introduced very early (Thomson 1922), and so their rate of introduction progressively decreased through time. In contrast, BI neophytes are still being drawn from the cosmopolitan pool of more than 20,000 potential invaders already present in New Zealand in cultivation or as ornamental garden plants (Lee et al. 2000; Sullivan et al. 2005).

This central role of habitat legacy is consistent with recent studies, which have highlighted the relevance of species' habitat affinities in their native range as a factor driving invasion dynamics (Hejda et al. 2009; Kalusová et al. 2013; Pyšek et al. 2015). Note here that while BI neophytes originated mostly from outside Europe, historically, most alien species in NZ, including BI neophytes, were introduced by European settlers, especially in the 19th century, when the commercial relations between New Zealand and other parts of the world were much weaker than today and before modern biosecurity methods reduced opportunities for introduction.

In summary, our findings suggest that observed patterns of beta diversity among NZ cities can be attributed to an interaction between differences in residence times and pre-adaptation to urban habitats that evolved or were filtered in association with anthropogenic activities before the species were moved to the invaded range. Therefore, when dealing with urban environments, a long-term trajectory can be recognized, for which pre-adaptations to disturbed anthropogenic habitats in one region contributes to the early introduction into similar habitats in other regions.

Acknowledgements Thanks to John Wilson for helpful comments on a previous draft of this paper, and to Leon Perrie (WELT), Ewen Cameron and Dhahara Ranatunga (AK) and Ines Schonberger (CHR) for arrival dates of invading Poaceae in New Zealand. PP was supported by long-term research development project RVO 67985939, Centre of Excellence PLADIAS No. 14-36079G from Czech Science Foundation, and Praemium Academiae award from The Czech Academy of Sciences. An early version of this paper was presented at a workshop on 'Non-native species in urban environments: Patterns, processes, impacts and challenges' hosted and funded by the DST-NRF Centre of Excellence for Invasion Biology (CIB) in Stellenbosch, South Africa, in November 2016. 


\section{References}

Anderson MJ (2004) PERMDISP: a FORTRAN computer program for permutational analysis of multivariate dispersions (for any two-factor ANOVA design) using permutation tests. University of Auckland, Department of Statistics, Auckland

Aronson MFJ, La Sorte FA, Nilon CH, Katti M, Goddard MA, Lepczyk CA, Warren PS, Williams NSG, Cilliers S, Clarkson B, Dobbs C, Dolan R, Hedblom M, Klotz S, Louwe Koojimans J, Kühn I, MacGregor-Fors I, McDonnell M, Mörtberg U, Pyšek P, Siebert S, Sushinsky J, Werner P, Winter M (2014) A global analysis of the impacts of urbanization on bird and plant diversity reveals key anthropogenic drivers. Proc R Soc B 281:20133330

Asmus U, Rapson GL (2014) Floristic homogeneity underlies environmental diversification of northern New Zealand urban areas. NZ J Bot 52:285-303

Blackburn TM, Essl F, Evans T, Hulme PE, Jeschke JM, Kühn I, Kumschick S, Marková Z, Mrugała A, Nentwig W, Pergl J, Pyšek P, Rabitsch W, Ricciardi A, Richardson DM, Sendek A, Vilà M, Wilson JRU, Winter M, Genovesi P, Bacher S (2014) A unified classification of alien species based on the magnitude of their environmental impacts. PLoS Biol 12:e1001850

Bonthoux S, Brun M, Di Pietro F, Greulich S, Bouché-Pillon S (2014) How can wastelands promote biodiversity in cities? A review. Landsc Urban Plan 132:79-88

Burton RM (1983) Flora of the London area. London Natural History Society, London

Cadbury DA, Hawkes JG, Readett RC (1971) A computermapped flora: a study of the county of Warwickshire. Academic Press, London

Castro SA, Figueroa JA, Muñoz-Schick M, Jaksic FM (2005) Minimum residence time, biogeographic origin, and life cycle as determinants of the geographic extent of naturalized plants in continental Chile. Divers Distrib 11:183-191

Chocholoušková Z, Pyšek P (2003) Changes in composition and structure of urban flora over 120 years: a case study of the city of Plzeň. Flora 198:366-376

Chytrý M, Jarošík V, Pyšek P, Hájek O, Knollová I, Tichý L, Danihelka J (2008a) Separating habitat invasibility by alien plants from the actual level of invasion. Ecology 89:1541-1553

Chytrý M, Maskell LC, Pino J, Pyšek P, Vilà M, Font X, Smart SM (2008b) Habitat invasions by alien plants: a quantitative comparison among Mediterranean, subcontinental and oceanic regions of Europe. J Appl Ecol 45:448-458

Crackles FE (1990) Flora of the east riding of Yorkshire. Hull University Press, Hull

Druett J (1983) Exotic intruders: the introduction of plants and animals into New Zealand. Heinemann, Auckland

Edgar E, Connor H (2000) Flora of New Zealand, volume V: Gramineae. Manaaki Whenua Press, Lincoln

Essl F, Dullinger S, Rabitsch W, Hulme PE, Hülber K, Jarošík V, Kleinbauer I, Krausmann F, Kühn I, Nentwig W, Vilà M, Genovesi P, Gherardi F, Desprez-Loustau M-L, Roques A, Pyšek P (2011) Socioeconomic legacy yields an invasion debt. Proc Natl Acad Sci USA 108:203-207
Fornal-Pieniak B, Chyliński K (2012) Diversity of spontaneous flora of unused industrial buildings in Warsaw, Poland. Ekológia (Bratislava) 31:379-389

Gassó N, Pyšek P, Vilà M, Williamson M (2010) Spreading to a limit: the time required for a neophyte to reach its maximum range. Divers Distrib 16:310-311

Hall PC (1980) Sussex plant atlas: An atlas of the distribution of wild plants in Sussex. Booth Museum of Natural History, Borough of Brighton, UK

Healy AJ, Edgar E (1980) Flora of New Zealand, volume III: adventive cyperaceous, petalous and spathaceous monocotyledons. Department of Scientific and Industrial Research, Botany Division, Lincoln

Hejda M, Pyšek P, Pergl J, Sádlo J, Chytrý M, Jarošík V (2009) Invasion success of alien plants: do habitats affinities in the native distribution range matter? Global Ecol Biogeogr 18:372-382

Ivimey-Cook RB (1984) Atlas of the Devon flora. Devonshire Association for the Advancement of Science, Literature and Art, Exeter, UK

Jackson PW, Skeffington MS (1984) Flora of inner Dublin. Royal Dublin Society, Dublin

Kalusová V, Chytrý M, Kartesz JT, Nishino M, Pyšek P (2013) Where do they come from and where do they go? European habitats as donors of alien plants globally. Divers Distrib 19:199-214

Knapp S, Kühn I, Schweiger O, Klotz S (2008) Challenging urban species diversity: contrasting phylogenetic patterns across plant functional groups in Germany. Ecol Lett 11:1054-1064

Kühn I, Klotz S (2006) Urbanisation and homogenizationcomparing the floras of urban and rural areas in Germany. Biol Conserv 127:292-300

Kühn I, Brandl R, Klotz S (2004) The flora of German cities is naturally species rich. Evol Ecol Res 6:749-764

Kühn I, Wolf J, Schneider A (2017) Is there an urban effect in alien plant invasions? Biol Inv, this issue

Kumschick S, Gaertner M, Vilà M, Essl F, Jeschke JM, Pyšek P, Ricciardi A, Bacher S, Blackburn TM, Dick JTA, Evans T, Hulme PE, Kühn I, Mrugała A, Pergl J, Rabitsch W, Richardson DM, Sendek A, Winter M (2015) Ecological impacts of alien species: quantification, scope, caveats and recommendations. Bioscience 65:55-63

La Sorte FA, McKinney ML (2006) Compositional similarity and the distribution of geographic range size for native and non-native species in urban floras. Divers Distrib 12:679-686

La Sorte FA, Pyšek P (2009) Extra-regional residence time as a correlate of plant invasiveness: European archaeophytes in North America. Ecology 90:2589-2597

La Sorte FA, McKinney ML, Pyšek P (2007) Compositional similarity among urban floras within and across continents: biogeographical consequences of human mediated biotic interchange. Global Change Biol 13:913-921

La Sorte FA, McKinney ML, Pyšek P, Klotz S, Rapson GL, Celesti-Grapow L, Thompson K (2008) Distance decay of similarity among European urban floras: the impact of anthropogenic activities on beta diversity. Global Ecol Biogeogr 17:363-371

La Sorte FA, Aronson MFJ, Williams NSG, Celesti-Grapow L, Cilliers S, Clarkson BD, Dolan RW, Hipp A, Klotz S, Kühn 
I, Pyšek P, Siebert S, Winter M (2014) Beta diversity of urban floras among European and non-European cities. Global Ecol Biogeogr 23:769-779

Lavin JC, Wilmore GTD (1994) The West Yorkshire plant atlas. City of Bradford Metropolitan Council, UK

Lee WG, Williams P, Cameron E (2000) Plant invasions in urban environments: the key to limiting new weeds in New Zealand. In: Suckling DM, Stevens PS (eds) Managing urban weeds and pests. The New Zealand Plant Protection Society, Lincoln, pp 43-58

Lososová Z, Chytrý M, Tichý L, Danihelka J, Fajmon K, Hájek O, Kintrová K, Láníková D, Otýpková Z, Řehořek V (2012) Biotic homogenization of Central European urban floras depends on residence time of alien species and habitat types. Biol Conserv 145:179-184

Lososová Z, Chytrý M, Tichý L, Danihelka J, Ricotta C (2016) Biotic homogenization of urban floras by alien species: the role of species turnover and richness difference. J Veg Sci 27:452-459

McKinney ML (2004) Do exotics homogenize or differentiate communities? Roles of sampling and exotic species richness. Biol Invasions 6:495-504

McKinney ML (2006) Urbanization as a major cause of biotic homogenization. Biol Conserv 127:247-260

McKinney ML, Lockwood JL (1999) Biotic homogenization: a few winners replacing many losers in the next mass extinction. Trends Ecol Evol 14:450-453

Middleton R (1998) The plants of Hull: an electronic atlas. Naturalist 123:24-26

Nedelcheva A (2011) Observations on the wall flora of Kyustendil (Bulgaria). Eur Asia J BioSci 5:80-90

Podani J, Schmera D (2016) Once again on the components of pairwise beta diversity. Ecol Inf 32:63-68

Primavesi AL, Evans PA (1988) Flora of Leicestershire. Leicestershire Museums Publication No. 89. Leicester, UK

Pyšek P (1998) Alien and native species in Central European urban floras: a quantitative comparison. J Biogeogr 25:155-163

Pyšek P, Jarošík V (2005) Residence time determines the distribution of alien plants. In: Inderjit (ed) Invasive plants: ecological and agricultural aspects. Birkhäuser, Basel, pp 77-96

Pyšek P, Richardson DM (2007) Traits associated with invasiveness in alien plants: where do we stand? In: Nentwig W (ed) Biological invasions. Springer, Berlin, pp 97-125

Pyšek P, Jarošík V, Pergl J, Randall R, Chytrý M, Kühn I, Tichý L, Danihelka J, Chrtek J, Sádlo J (2009) The global invasion success of Central European plants is related to distribution characteristics in their native range and species traits. Divers Distrib 15:891-903

Pyšek P, Bacher S, Chytrý M, Jarošík V, Wild J, Celesti-Grapow L, Gassó N, Kenis M, Lambdon PW, Nentwig W, Pergl J, Roques A, Sádlo J, Solarz W, Vilà M, Hulme PE (2010) Contrasting patterns in the invasions of European terrestrial and freshwater habitats by alien plants, insects and vertebrates. Global Ecol Biogeogr 19:317-331

Pyšek P, Jarošík V, Hulme PE, Pergl J, Hejda M, Schaffner U, Vilà M (2012) A global assessment of invasive plant impacts on resident species, communities and ecosystems: the interaction of impact measures, invading species' traits and environment. Global Change Biol 18:1725-1737
Pyšek P, Manceur AM, Alba C, McGregor KF, Pergl J, Štajerová K, Chytrý M, Danihelka J, Kartesz J, Klimešová J, Lučanová M, Moravcová L, Nishino M, Sádlo J, Suda J, Tichý L, Kühn I (2015) Naturalization of central European plants in North America: species traits, habitats, propagule pressure, residence time. Ecology 96:762-774

Rejmánek M (2000) Invasive plants: approaches and predictions. Austral Ecol 25:497-506

Richardson DM, Pyšek P (2006) Plant invasions: merging the concepts of species invasiveness and community invasibility. Prog Phys Geog 30:409-431

Richardson DM, Pyšek P, Rejmánek M, Barbour MB, Panetta FD, West CJ (2000) Naturalization and invasion of alien plants: concepts and definitions. Divers Distrib 6:93-107

Ricotta C, La Sorte FA, Pyšek P, Rapson GL, Celesti-Grapow L, Thompson K (2009) Phyloecology of urban alien floras. J Ecol 97:1243-1251

Ricotta C, La Sorte FA, Pyšek P, Rapson GL, Celesti-Grapow L, Thompson K (2012) Phylogenetic beta diversity of native and alien species in European urban floras. Global Ecol Biogeogr 21:751-759

Ricotta C, Celesti-Grapow L, Kühn I, Rapson G, Pyšek P, La Sorte FA, Thompson K (2014) Geographical constraints are stronger than invasion pattern for European urban floras. PLoS ONE 9:e85661

Sádlo J, Chytrý M, Pyšek P (2007) Regional species pools of vascular plants in habitats of the Czech Republic. Preslia 79:303-321

Shaw M (1988) A flora of the Sheffield area (two hundred years of plant records). Sorby Natural History Society, Special Series No. 8, Sheffield, UK

Simberloff D, Martin J-L, Genovesi P, Maris V, Wardle DA, Aronson J, Courchamp F, Galil B, García-Berthou E, Pascal M, Pyšek P, Sousa R, Tabacchi E, Vilà M (2013) Impacts of biological invasions: what's what and the way forward. Trends Ecol Evol 28:58-66

Stace CA (2010) New Flora of the British Isles, 3rd edn. Cambrdige University Press, Cambridge

Stace CA, Crawley MJ (2015) Alien plants. Collins New Naturalist Library, London

Stevens RA (1990) A provisional flora and habitat atlas of Plymouth. Nature Conservancy Council, Plymouth

Sukopp H, Werner P (1983) Urban environments and vegetation. In: Holzner W, Werger MJA, Ikusima I (eds) Man's impact on vegetation. Dr. W Junk Academic Publisher, The Hague, pp 247-260

Sullivan JJ, Timmins SM, Williams PA (2005) Movement of exotic plants into coastal native forests from gardens in northern New Zealand. NZ J Ecol 29:1-10

Thomson GH (1922) The naturalisation of animals and plants in New Zealand. Cambridge University Press, Cambridge

van Kleunen M, Dawson W, Schaepfer D, Jeschke JM, Fischer M (2010a) Are invaders different? A conceptual framework of comparative approaches for assessing determinants of invasiveness. Ecol Lett 13:947-958

van Kleunen M, Weber E, Fischer M (2010b) A meta-analysis of trait differences between invasive and non-invasive plant species. Ecol Lett 13:235-245

Veltman CJ, Nee S, Crawley MJ (1996) Correlates of introduction success in exotic New Zealand birds. Am Nat 148:542-557 
Vilà M, Espinar JL, Hejda M, Hulme PE, Jarošík V, Maron JL, Pergl J, Schaffner U, Sun Y, Pyšek P (2011) Ecological impacts of invasive alien plants: a meta-analysis of their effects on species, communities and ecosystems. Ecol Lett 14:702-708

Webb CJ, Sykes WR, Garnock-Jones PJ (1988) Flora of New Zealand, Volume IV: Naturalised Pteridophytes, gymnosperms, dicotyledons. Department of Scientific and Industrial Research, Botany Division, Christchurch, NZ

Williamson M, Dehnen-Schmutz K, Kühn I, Hill M, Klotz S, Milbau A, Stout J, Pyšek P (2009) The distribution of range sizes of native and alien plants in four European countries and the effects of residence time. Divers Distrib 15:158-166

Wilson JRU, Richardson DM, Rouget M, Proches S, Amis MA, Henderson L, Thuiller W (2007) Residence time and potential range: crucial considerations in modelling plant invasions. Divers Distrib 13:11-22

Winter M, Schweiger O, Klotz S, Nentwig W, Andriopoulos P, Arianoutsou M, Basnou C, Delipetrou P, Didžiulis V, Hejda M, Hulme PE, Lambdon PW, Pergl J, Pyšek P, Roy DB, Kühn I (2009) Plant extinctions and introductions lead to phylogenetic and taxonomic homogenization of the European flora. Proc Natl Acad Sci USA 106:21721-21725 